\title{
Author Correction: Synthetic CRISPR-Cas gene activators for transcriptional reprogramming in bacteria
}

\author{
Chen Dong', Jason Fontana², Anika Patel', James M. Carothers (iD ${ }^{2,3,4}$ \& Jesse G. Zalatan (1) 1,2,4
}

Correction to: Nature Communications https://doi.org/10.1038/s41467-018-04901-6; published online 27 June 2018

In the original version of the Supplementary Information file associated with this Article, the sequence '1x MS2 scRNA.b2' was incorrectly given as 'GAAGATCCGGCCTGCAGCCAGTTTTAGAGCTAGAAATAGCAAGTTAAAATAAGGCTAGTCCGTTATCA ACTTGAAAAAGTGGCGCACATGAGGATCACCCATGTGCTTTTTT' and should have read 'GAAGATCCGGCCTGCAGCCAGT TTTAGAGCTAGAAATAGCAAGTTAAAATAAGGCTAGTCCGTTATCAACTTGAAAAAGTGGCACATGAGGATCACCCATGT GCTTTTTTT'. The error has now been fixed and the corrected version of the Supplementary Information PDF is available to download from the HTML version of the Article.

Published online: 15 October 2018

Open Access This article is licensed under a Creative Commons Attribution 4.0 International License, which permits use, sharing, adaptation, distribution and reproduction in any medium or format, as long as you give appropriate credit to the original author(s) and the source, provide a link to the Creative Commons license, and indicate if changes were made. The images or other third party material in this article are included in the article's Creative Commons license, unless indicated otherwise in a credit line to the material. If material is not included in the article's Creative Commons license and your intended use is not permitted by statutory regulation or exceeds the permitted use, you will need to obtain permission directly from the copyright holder. To view a copy of this license, visit http://creativecommons.org/licenses/by/4.0/.
\end{abstract}

(C) The Author(s) 2018

\footnotetext{
${ }^{1}$ Department of Chemistry, University of Washington, Seattle, WA 98195, USA. ${ }^{2}$ Molecular Engineering \& Sciences Institute, University of Washington, Seattle, WA 98195, USA. ${ }^{3}$ Department of Chemical Engineering, University of Washington, Seattle, WA 98195, USA. ${ }^{4}$ Center for Synthetic Biology, University of Washington, Seattle, WA 98195, USA. Correspondence and requests for materials should be addressed to J.M.C. (email: jcaroth@uw.edu) or to J.G.Z. (email: zalatan@uw.edu)
} 